\title{
Long and Short Term Effect of China's Non Oil Import Dominance in Nigeria
}

\author{
Oseni Michael
}

\author{
Department of Accountancy, The Polytechnic, Ibadan, Nigeria.
}

osenimike@gmail.com

\section{Doi:10.5901/mjss.2014.v5n10p156}

\begin{abstract}
China's import to Nigeria has been going up in the past decade compared to Nigeria's export to the country which was significantly very low. This has resulted in an unfavourable balance of trade against Nigeria. Data used for this study is sourced from Central Bank of Nigeria Annual Report 2012 in respect of non oil import by country of origin. Imports from all the industrialized nations are a little more than that of China. China has involved itself in every aspect of Nigerian economy like road construction, railway, power plants and telecommunication engineering. The hitherto country which Nigerian citizens found difficult travelling to had relaxed its entry requirement by granting visa exemption to Nigerian government officials. The future of trade relationship between China and Nigeria was further analysed and it was recommended that China should involve itself in manufacturing in Nigeria rather than exporting its finished goods to the country as this will increase the country's Gross Domestic Product and reduce unemployment among the teeming youths. Dumping should be discouraged in all its ramifications. Unskilled labour especially in construction companies should be given to the locals instead of exporting it into the country.
\end{abstract}

Keywords: Chinco, International trade, Import, Non oil imports, Industrialised nations

\section{Introduction}

Pre-colonial periods in Nigeria witnessed many types of trades from slave trading involving human trafficking to merchants looking for raw materials for various factories that were in operation due to the advent of industrial revolution in Europe. Raw materials for these industries were plentiful- from rubber, cotton, shea butter, hides and skin to palm oil. The demand for industrial goods made these merchants to search for raw materials that were plentiful in the region. Trade by barter was the means of settlement. In exchange for these raw materials and slaves, arms and ammunition, spirits and other exotic goods were made available. The slaves were mainly exported to the new world (Americas) where they worked in cotton, sugar and cocoa plantations. These agricultural products were then exported to the already established factories in the European countries thereby establishing the famous triangular slave trade.

The various expeditions to the interior of Africa were mainly in search of alternative routes to transport these potential raw materials at cheaper cost to the factories based in European countries. The belief was that there were many rivers in the hinterland which would naturally lead to the oceans or big inland lakes.

The slave trade was brought to an end in the $19^{\text {th }}$ century due to the humanitarian efforts of abolitionists and the various governments that supported them. Slave trade was declared illegal as from 1807 in Great Britain before slavery itself was totally wiped out. The hitherto plantations were no more after the abolition of slave trade as slave labour were unavailable to cultivate these lands. This therefore affected the industries as raw materials were no longer available.

The partition of Africa in 1885 was based mainly on the potentialities of regions and basically what each region could provide for the imperial-based industries at home. That was one of the reasons that caused fierce struggles in the west coast of Africa than most other parts. Consideration for language, culture and other intrinsic parameters for creating countries or states were set aside. Rather, what could be the potential products from the lands were of paramount importance. The race to Nikki by the French and the British was typical of this where the Yoruba nation was divided into two between the British and French imperialists. Partitioned regions had their citizens domiciled in these regions with colony and protectorate status.

Britain granted the Royal Niger Company a trading monopoly in the north. The company later advanced economic and political interests of the British. Executive and legislative functions were performed by setting up a para-military unit and powers to settle disputes among the natives and other white traders. It later set up headquarters at Lokoja, located at the confluence of the Niger and Benue rivers in central Nigeria, and extended its trade northwest and north east of the Niger and Benue respectively. Treaties were signed with several African states on behalf of the British. It traded mainly in 
household utensils, farm equipments, textile, liquor and spirits. In exchange for these are exported products which were mainly palm produce that served the industries in Western Europe.

The liberated slaves that returned to West Africa brought with them the new products of the New Word. Cocoa and coffee were brought from Brazil where the climate and the soil were nearly the same with that of the west coast of Africa. These crops became the life saving and economic trees of the people. A typical type of rice called ofada (nickname given to the person who smuggled the seedlings out of the Caribbean) did excellently well in the south western part of Nigeria.

After the abolition of the slave trade and the industrial revolution was at its peak, there was shortage of raw materials that were hitherto supplied mainly from the new word. It was then imperative that alternative source of raw materials should be made available for these industries. The colonial rulers started encouraging people to establish plantations which was strange to the Africans. Rubber, cocoa, coffee and palm plantations were introduced in order to supply the necessary raw materials to the factories in the Western Europe. The finished goods, after satisfying the home consumption, were exported back to Africa where the raw materials were sourced.

In nearly all West African countries during the 60s, the types of goods consumed show clearly the attachment of that country to its past colonial master. In francophone countries, vehicles like Peugeot, Citroen, and Renault were common, while Opel, Bedford, and Austin vehicles could easily be seen in streets in Nigeria and Ghana. The exported goods, which were mainly agricultural produces from these countries were mainly to the countries of their past colonial masters. Most of Nigeria's cocoa, rubber and palm produce were destined to British factories and the same thing for Gambia's peanuts and Ghana's cocoa.

But of recent in Nigeria was the generally observed trend which has changed significantly from what it has used to be since Nigeria's independence. There seem to be a significant shift in respect of imported goods into the country. Far East countries are now having significant imports into the countries than the western countries put together. In 2009, the total imports from European countries amounted to N1,631,803 million while that of Asian countries were N 1,896,085.9 million. In 2010, it was N1,618,626.3 million to N 2,496,640.9 for European and Asian countries respectively (National Bureau of Statistics, 2011). Of significance is China's export to Nigeria during these periods. China exports to Nigeria were N 893,194.70 million and N 1,100,780.5 million for 2009 and 2010 respectively. These amounted to 54.7\% and 68\% of all European countries' exports to Nigeria during the same period.

The influx of Asian goods is noticeable in the country. The Lagos state government has initiated the teaching of Chinese language in its secondary school curriculum. This may be an attempt to easily checkmate the difficulties that may be encountered in interpreting the instructional manuals of these exported goods being used in the country (Oladunjoye, 2012).

Is Nigeria gradually shifting from its traditional trade partners in favour of its new trade partners from the Far East? Are these goods from these countries cheaper and of better quality than that from European countries? What factors contributed to this sudden change of higher imports and what would be the effect of inventory management of these goods? These and other pertinent inquiries will be the focus of this paper. The rest of the paper is then divided into four sections. Conceptual framework and literature review is in chapter two; section three is on research methodology while section four is on findings and discussion. Section five summarizes, concludes and recommends.

\section{Conceptual Framework and Literature Review}

\subsection{Conceptual Framework}

\subsubsection{International trade}

Economic transactions along international borders between two countries in which a nation exchanges commodity it lacks in exchange for those that it produces in abundance is normally called international trade. It is facilitated by international financial payments that involve the banking system and the central banks of the trading nations. The economy of the world is affected by the exchange of goods and services which are available to the consumers globally. International relations among countries facilitate freer trade between nations.

The nationalistic school of thought also called the Mercantilism in the $16^{\text {th }}$ and $17^{\text {th }}$ centuries insisted that the acquisition of wealth was of paramount importance for national policy and that a nation can increase its trade only at the expense of other nations. It is the responsibility of the government to promote exports of finished goods and imports of raw materials, while at the same time the exports of raw materials and the imports of finished goods are controlled. After Adam Smith's publication of The Wealth of Nations in 1776 specifically stating the advantages of removing trade restrictions, economists and businessmen voiced their opposition to excessively high and often prohibitive customs duties 
and urged negotiation of trade agreements with foreign powers.

\subsubsection{Import}

Goods brought into a jurisdiction, especially across a national border from an external source are regarded as import. The receiving party is normally called the importer while the sender or the giver is called the exporter. Imports consist of transactions in goods and services (sales, barter, gifts or grants) from non-residents to residents. It therefore means that an import in the receiving country is an export from the sending country. Importation and exportation are limited by importation quotas and mandates from the custom authorities. Data on international trade in goods are mostly obtained through declarations to custom services. If a country applies the general trade system, all goods entering the country are recorded as imports. Basic statistics on international trade normally do not record smuggled goods or international flows of illegal services. A small fraction of the smuggled goods and illegal services may nevertheless be included in official trade statistics through dummy shipments or dummy declarations that serve to conceal the illegal nature of the activities. There are two basic types of import. These are: Industrial and consumer goods and Intermediate goods and services. The former may comprise equipments, plants and machinery, industrial raw materials or household equipments. Import of services may be in form of human resources and other technical services like engineering, surveying and production expertise.

\subsubsection{Balance of trade}

A difference in value for import and export for a country is the balance of trade. A country has demand for an import when domestic quantity demanded exceeds domestic quantity supplied or available. It may also occur when the price of the good (or service) on the world market is less than the price on the domestic market. The balance of trade is the difference between the value of the goods and services a country exports and the value of the goods the country imports. A trade deficit occurs when the value of imports are more than the value of exports while trade surplus is the other way round. Imports are impacted principally by a country's income and its productive resources. The two important factors affecting imports are domestic absorption and real exchange rate.

\subsection{Literature review}

With advent of Nigeria's civilian dispensation in 1999, new trading partners were being added to the existing ones. Britain which had been Nigeria's top trading partner had its position overtaken by countries from the Asian continents. China which had been a non-aligned nation had now taken a prominent position as the largest trading partner with Nigeria. Before China's economic reform policies of the 1970s and 1980s there were few trade contacts with African markets. Most trading partners in the sub-African region were of the imperial nature. Past colonial masters intensified their trading concerns in the countries where they had entrenched their economic prowess. China which had never had any imperial domination in Africa started trading in a different way. Utomi (1998) asserted that China's early contact in trade with Africa countries was different from that of Western partnership. Prior to 1999, Nigeria was regarded as a pariah nation and because of this stature; very few developed nations had any meaningful commercial and technological transactions with it. But as soon as Obasanjo's administration came up in 1999, the tempo changed and many industrialized nations started trading with Nigeria. Trade between China and Nigeria was particularly of geometrical proportion (Momoh, (2009).

Nigeria's support of the national liberation movements against apartheid regimes in southern Africa which gave it the status of a self-styled frontline state strengthened its diplomatic relations with China. This was as a result of China's relationship with Africa that shifted from indirect political and ideological support to direct support for various national liberation movements (Utomi, 1998).

It was after the liberation of the Chinese economy in 1989 by Deng Xiao Ping that the country moved from a Third World country to one of the most influential economic powers in the world. This has resulted in moving the country from the once reputed communist enclave to any western country as far as capitalistic economy is concerned. Arinze (2012) posited that a reasonable percentage of Nigeria's imported materials and goods come from China with little or nothing exported there. This according to him has made manufacturers to be suffering. He then suggested that setting up industries will provide employment that will correct the trade imbalance.

Nabine (2009) is of the opinion that the bilateral trade between China and Nigeria, in the short run, doesn't contribute to Nigeria economic growth but the long term relationship can enhance Nigeria economic growth. To benefit from China, greater emphasis should be placed on building human capital and overcoming language and cultural barriers 
to facilitate the transfer of business knowledge and technology to a wider array of the Nigerian population. He further recommends that there should be exchanges between Chinese and Nigerian businessmen in the manufacturing sector as a first step.

Comparative advantage can make a firm to excel which invariably is applicable to the economy of the nations. In an earlier study on implications of Nigeria-China trade relations, findings show a trade imbalance in favour of China and it was recommended that Nigerian government should encourage massive direct investment and the location of production facilities in Nigeria by the Chinese firms rather than involving in only trade relations to correct the imbalance and provide more jobs for Nigerians (Ayoola, 2013).

China's main interest in Africa in the 1960s up to 1970s was to entrench its communist ideology to the underdeveloped nations where western capitalists were operating. But immediately after the cold war, pragmatic interests in trade, investment and energy were vigorously pursued. Later, the western power bloc domination of Africa's trade, politics and international relationships were gradually being threatened by escalating Chinese influence in Africa. Brookes and Shin (2006) put forward two reasons for China's active participation in Africa mainly to be securing supplies of natural resources so as to counter Western political power and also to isolate Taiwan. They concluded that it would be in America's interest to deftly encourage democratic processes, economic freedom, and respect for human rights across the African continent in order to address these developments.

Availability of natural resources in developing countries was one of the reasons that propelled China to start investing in these countries in 1990s. The developing countries most affected by China over the last decade are those rich in natural resources. Many of these countries, such as Angola, Venezuela, Zimbabwe, and Zambia, have been cited as countries that had suffered from the resource curse. This resource curse inhibits resource-rich developing countries to perform worse than those with fewer natural resources. Resource-rich developing countries tend to perform worse than those with fewer natural resources (Rice, 2011). Since Nigeria according to Momoh (2009) has abundant raw materials available in commercial quantity, the Chinese, in order to boost their productive sectors, had African countries as their targets. Thereafter, the Chinese intensified their raw material procurement all over Africa.

Nigeria being the most populous country in Africa had taken an immeasurable percentage of trade between China and African continent. One-third of the volume of trade between Africa and China was currently taking place with Nigeria. And therefore the business operation of China in Nigeria is significant (Jonathan, 2014).

Wadhwa (2013) asserted that trade between Nigeria and China is skewed. China's major imports from Nigeria are the crude oil and natural gas. These accounted for only $2 \%$ of China's total imports from Africa whereas Nigeria is a top export destination of Chinese goods and foreign direct investments. In helping Nigeria transforming into Africa' largest economy, Chinese state owned enterprises - CNPC, Sinopec, Huawei, and ZTE to name a few, have directed much of their attention to updating Nigeria's power, transport and resource-extraction infrastructure. Chinese contracts, he concluded, have flooded domestic markets with affordable goods, modern machinery, and an improved national infrastructure.

\section{Research Methodology}

\subsection{Data Structure and Technique of Analysis}

Secondary data were used for the purpose of this study. Data were sourced and collected from relevant materials such as textbooks, Newspapers, Journals and other official documents. Data in respect of non oil imports by country of origin in the Annual Reports of Central Bank of Nigeria for 2012 were used. Non oil imports from 2008 to 2012 of industrial nations, United States, United Kingdom, China, Africa and the rest of the world were extracted. United States of America and United Kingdom belong to the industrial nations but imports from these countries were shown separately again because of their importance. Britain was Nigeria's colonial master and United States was a key player in Nigerian international trade. The rest of Africa was also taken as a single entity to show the country's (being the largest in Africa) international relationship with the rest of the continent. Descriptive statistics is used to analyse data sourced. (APPENDICES $A$ and $B$ )

\section{Findings and Discussion}

The value of non oil import into Nigeria between 2008 and 2012 showed a steady and commanding increase for China compared to other countries. In 2008, the value of the imports for all the industrial nations was $39.5 \%$ of the total non oil imports compared to that of China (a single country) which was 14\%. The value of import from China rose steadily 
throughout the period under study but that of the industrialised nations dropped in 2009 before rising again in 2010. In 2012, industrialised nations and China had $42.8 \%$ and $30.5 \%$ respectively for all the total non oil imports into Nigeria. China had more than $30 \%$ of all the value of all imports in 2012. (APPENDIX A).

The tempo of China's trading relationship was jacked up when the military dictatorship came to an end in 1999. All along, Nigeria had been a supporter of one united China in which Taiwan is an integral part of the Chinese nation. The return of Hong Kong by Britain to China was also supported as Nigeria had all along regarded Hong Kong to be a trading post (Momoh, 2009).

The relationship between China and Nigeria goes beyond commerce. As a developing country which is nonaligned, fast tracking the process of development and growth of Nigeria is paramount to the top echelon of political apparatus. It was during the visit of the former National Chairman of the Peoples Democratic Party (PDP), Alhaji Bamanga Tukur when Mr Ai Ping, the Vice Minister, International Department of CPC Central Committee stressed that for Nigeria to tap from its tested wisdom in nation building, it must struggle hard to tackle what he described as four evils which he reckoned has been bedeviling Nigeria and most African countries for long. The four evils, according to him are feudalism which he stressed promotes indiscipline, extravagance and corruption, poor leadership and party system as well as weak institutions. He said Nigeria should not shy away from recruiting experts from relevant quarters to train its youths on acquisition of skills which is vital to national growth.

Chinese firms operating in Nigeria are more than 200 as at the end of 2013. Annual Nigerian-Chinese trade increased nine-fold, from $\$ 2$ billion to $\$ 18$ billion between 2000 and 2010. During the period, bilateral agreements concerning commerce, agriculture, tourism and security were signed. Nigeria imported more goods from China in 2012 than it did from the U.S. and India combined (Nigeria's number two and three import partners, respectively) (Wagner and Cafiero, 2013).

It was the idea of the Chinese government to exempt senior government officials and diplomats visiting China from the visa hurdles. They were to be exempted as from February 1 2014. This became imperative, according to the outgoing Chinese Ambassador to Nigeria, Deng Boqing at the Nigeria-China Business Roundtable and Luncheon in Lagos which was organised by the Nigerian Institute of International Affairs (News Agency of Nigeria, 2014). But visa exemption to senior government officials will tend to increase government bilateral relationship between the two countries, businessmen should be considered first when visa exemption is being considered. As several construction works in transportation, communications, roads, railways, airports, power plants and agro-allied projects are being carried out by Chinese contractors having governments principally as clients, such visa exemption to government officials is a fait accompli.

Islamic terrorism and extremism in Africa are now challenging the activities of the Chinese interest in commerce. This has led to tacit support in combating the insurgencies rearing their heads. This tacit support will not hinder the trade and investments China is having here. Expatriates are kidnapped in Niger Delta and the Chinese are not spared. Most construction companies in the South West of Nigeria are being guarded by fortified security details.

Nigeria joined the world in mobile telecommunication in 2001. Since then, the industry has been described as the fastest growing in black Africa. Telephone handsets which had hitherto the exclusive properties of the middle and upper level strata of the society are now common to most people in both the rural and urban centres. Many handsets commonly referred to as CHINCO (a coinage of cheap handset from China) has become the saving grace of the people. But this word 'chinco' which suggests cheap and inferior goods has parallel in some goods from industrialized nations. Honda Accord 1986 manufactured in Japan is called Honda 'Pure Water', because it is 'everywhere' while Toyota Camry 2005 is called 'Toyota Good for nothing'. These Chinese products which are technologically sophisticated like their counterparts from the Western Europe are likely to have impacts on the poor which will alleviate poverty as the goods imported are less heavily dependent on unskilled labour (Jenkins and Edwards, 2004).

The relationship between Nigeria and China is to be looked into. Which party is benefiting more than the other? Virtually all sectors of the Nigerian economy had been involved with Chinese commercial activities. Nigeria's private business community also exhibited mixed feelings about Chinese business incursions into Nigeria. Businessmen welcomed trading with a lower-cost economy, securing financing from Chinese partners, and learning from Chinese manufacturers and business models. Utomi (2008) was apprehensive of the risk of heightened dependence on China, its weak official leverage, quality of project implementation and uncertainty over technology transfer. He therefore suggested expanded debate within the Nigerian government and across the business, academic, and civil society communities on how best to optimize Western and Chinese engagement.

The imperial motive of China which is being speculated by the West was assuaged when the Chinese ambassador to South Africa Liu Guijin compared Columbus expedition to the New World to that of Zhen He who led the largest fleet in the world with 28 ships and 27,800 people on voyages that brought them to three continents, including Africa. They did 
not occupy an inch of any newly discovered land or set up any military fortress (Utomi, 2009).

The types of imports from China to Nigeria should be a matter of concern. Importing goods that are in abundance seem to be a way of turning the country to a dumping ground. A case in point is the importation of furniture to Nigeria where there is abundance of the product (Onadipe, 2014).

\section{Summary, Conclusions and Recommendations}

This paper examines imports from industrialised nation compared to that of China for a period of five years starting from 2008. Findings show that there was a steady rise and commanding rise of imported non oil imports from China compared to all other countries. The effect of China's influence in Nigeria could be felt in all spheres of lives in Nigeria. Road construction, railways, airports, power plants and telecommunications have significant presence of China's investment. The hitherto country that was regarded as a no go zone in the 1960s had now become a favourite country where government officials are exempted from visa. But what is Nigeria gaining from this incipient rise in imports without a corresponding rise in exports? Teaching a man how to fish is better than giving fish to him all the time. It is imperative for China to set up production facilities in the country instead of exporting finished goods as this would contribute to the productivity of Nigeria's economy which would ultimately increase the country's Gross Domestic Product. Nigerians should be more involved in unskilled labour being used by the Chinese engineering companies most especially in road construction. This will reduce unemployment among the youths. Other states in Nigeria like Lagos state should encourage the learning of Chinese language as this would ease language barrier that may be encountered in the application of goods imported from China. Bilateral trade relationship between the two countries in the long run should be appraised to find out the real benefits that will accrue to each of the two countries.

\section{References}

Arinze, A. (2012) Chinese Invasion of Nigeria Retrieved from http://arinze198.wordpress.co,/ on Saturday December 28, 2013

Ayoola, T. J. (2013) Nigeria-China Trade Relations: Implication on the Nigerian Domestic Economy, Research Journal of Finance and Accounting ISSN 2222-2847 (Online) Vol.4, No.17, 2013 www.ïste.org

Brookes, P and Shin, J. A. (2006) China's Influence in Africa: Implications for the United States Retrieved from www.heritage.org/.../chinas-influence-in-africa-implications-for-the-unit... on Tuesday January 14, 2014

Jenkins, R. and Edwards, C. (2004) How Does China's Growth Affect Poverty Reduction in Asia, Africa and Latin America? unpan1.un.org/intradoc/groups/public/documents/.../unpan035364.pdf

Jonathan, G. (2014) Nigeria responsible for one-third of Africa-China trade Retrieved from http://www.punchng.com/ on Thursday January 16, 2014

Momoh, S. (2009) How tidy is Nigeria-China relations (3) Retrieved from http://www.businessdayonline.com/ on Sunday January 26, 2014.

Nabine, D. (2009) The Impact of Chinese Investment and Trade on Nigeria Economic Growth African Trade Policy Centre, Work in Progress No.77 Economic Commission for Africa

National Bureau of Statistics, (2011) The Review of the Nigerian Economy 2010

News Agency of Nigeria (NAN) (2014) China announces visa exemption for Nigerian diplomats, officials Retrieved from http://premiumtimesng.com/search on Friday January 17, 2014.

Oladunjoye, O. (2012) Lagos to introduce Chinese language in public schools Retrieved from http://www.vanguardngr.com/2012/09/lasgto-introduce-chinese-language-in-public-schools/\#sthash.FUDr5fDg.dpuf on Tuesday February 11, 2014

Onadipe, S. (2014) Nigerians' notoriety in China is unprecedented Retrieved from www.vanguardngr.com/ on Monday February 17, 2014.

Rice, S. (2011) China to the Rescue? The Implications of China's Engagement with Resource-Rich Countries. Thesis submitted in partial fulfillment of the requirements for the degree of Bachelor of Arts in International Political Economy University of Puget Sound December 12, 2011 Retrieved from http://www.soundideas.pugesound.edu on Tuesday January 21, 2014.

Samuel, I. (2013) China identifies 4 evils bedevilling Nigeria Retrieved from http://www.tribune.ng/news2013/index.php/en/news/leadstories on Saturday December 28, 2013

Utomi, P. (2008) China in Nigeria, Centre for Strategic and International Studies csis.org/publication/china-nigeria

Utomi, P. (2009) China and Nigeria, Centre for Strategic and International Studies csis.org/...a/csis/pubs/080603_utomi_nigeriachina.pdf

Wagner, D. and Cafiero G (2013) China and Nigeria: Neo-Colonialism, South-South Solidarity, or Both? Retrieved from http://www.huffgtonpost.com/giorgio-cafiero on Tuesday January 28, 2014

Wadhwa, S. (2013) China in Nigeria: Skewed trade relations suggest potential for further involvement Retrieved from http://sites.dvidson.edu/pol341/tag/sudan on Tuesday February 4, 2014 


\section{Appendix A}

\begin{tabular}{|l|c|c|c|c|c|}
\hline & \multicolumn{5}{|c|}{ Non oil import by country of origin (c\&f) value (nm) } \\
\hline & 2008 & 2009 & 2010 & 2011 & 2012 \\
\hline Industrial countries & 1500683.37 & 1396527.90 & 2051879.72 & 2483737.88 & 2589825.82 \\
\hline United states of america & 505122.91 & 410378.40 & 577988.44 & 795020.13 & 674718.64 \\
\hline United kingdom & 199821.84 & 227779.53 & 294353.88 & 346437.50 & 255216.68 \\
\hline China & 534149.97 & 647892.74 & 987339.88 & 1397365.55 & 1843467.92 \\
\hline Africa & 96347.07 & 111109.07 & 157120.74 & 145757.30 & 115847.95 \\
\hline Others & 966947.52 & 1245302.56 & 1788832.99 & 1825749.46 & 570593.33 \\
\hline \multicolumn{1}{|c|}{ Total } & 3803072.68 & 4038990.20 & 5857515.65 & 6994067.82 & 6049670.34 \\
\hline
\end{tabular}

Source: Central Bank of Nigeria Annual Reports 2012

\section{Appendix B}

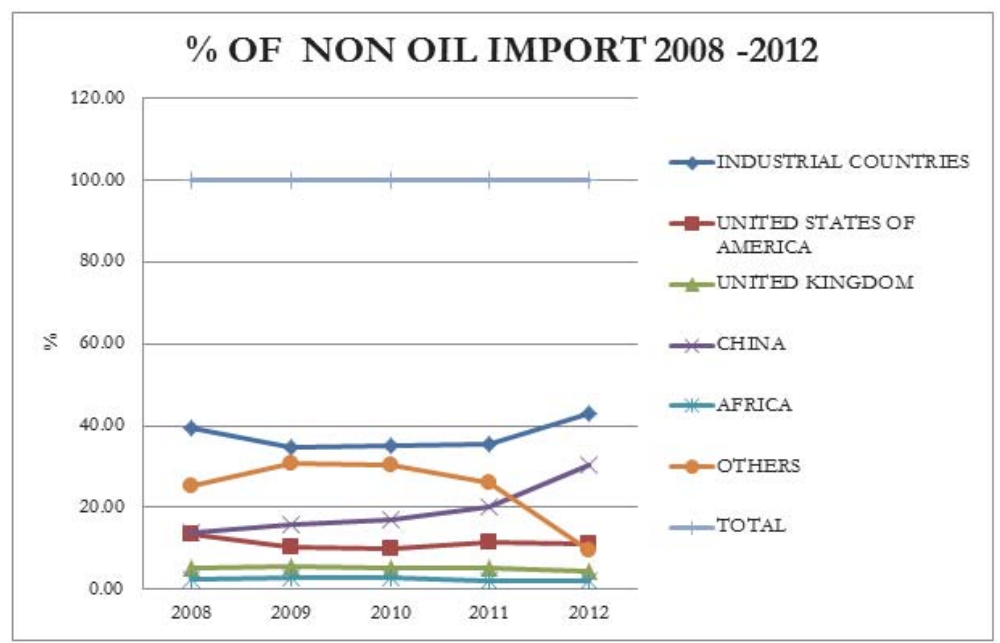

